\title{
Appreciation
}

\section{Professor Michael Davies, British Heart Foundation Professor of Cardiac Pathology, Editor of Heart 1992-1999}

Those who knew Michael Davies well will remember his firm view on the purpose of the Journal and therefore what follows must be an appreciation rather than an obituary; Mike strongly disapproved of the latter.

There is, however, ample purpose in writing about the man, for the personality was father to the successful scientist. Michael Davies was a world authority in the field of cardiac pathology, and one of the leading medical scientists of his generation. Working in the Pathology Department at St George's Hospital he was awarded the first British Heart Foundation Chair of Cardiovascular Pathology in 1981. He had an extensive practice providing second opinions in his specialised field and was a superb undergraduate teacher. A keen photographer, his slide collection was, and is, legendary, and he generously provided slides to many national and international speakers.

In 1992 he was appointed Editor of the British Heart Journal. He had a broad vision for the journal and was responsible for changing its name to Heart to reflect its growing international perspective. He worked hard on maintaining and improving the quality of the journal in a changing climate, and he was involved in the planning of the educational aspects of the journal which were introduced just after he gave up the editorship in 1999. From then until his death, Professor Davies extended his work with the British Heart Foundation as their Associate Medical Director for Research.

He had an uncompromising attitude to quality allied to a steely, single minded determination. His scientific observations were characterised by meticulous

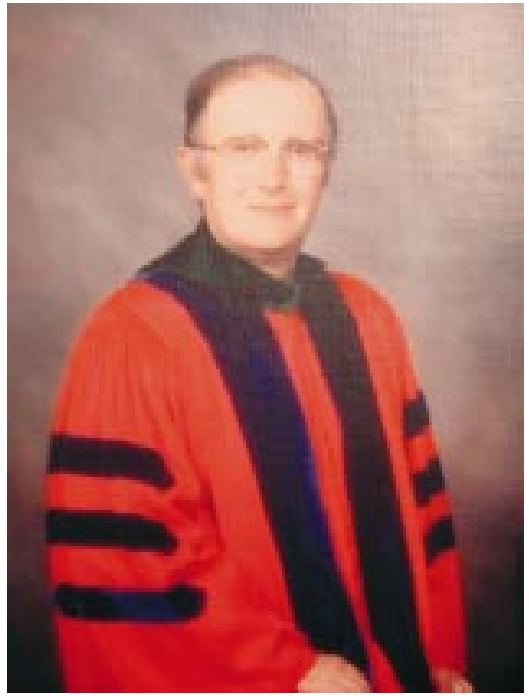

yet simple techniques, clarity of thought entirely uninfluenced by fashionable views or perceived wisdom, and the talent of a Grand Master in the lucid exposition of his conclusions, to the rest of the world. As Titian seduces us into an understanding of his subject, so Mike used his beautiful and carefully crafted slides to help cardiologists to understand coronary artery disease.

He was scrupulously honest and fair, a person of outstanding integrity; with Mike Davies the goalposts did not move. Despite his international reputation, he was a man without vanity. MJD had a gift for asking a simple but clinically relevant question, then organising research to provide an answer. Cardiac clinicians throughout the world have benefited from his insights into the conducting system of the heart, valve pathology, coronary disease, and cardiomyopathy.
From his youthful scientific support to Donald Teare in the first description of hypertrophic cardiomyopathy, to his elucidation of the now universally accepted concept of plaque instability, his own personality shone through. Patience and plenty of planning were parts of his scientific success. His work on plaque rupture has underpinned most of the developments in the understanding and treatment of coronary disease in recent years and fittingly he was presented with a Lifetime Achievement Award for this work at the 2001 American Heart Association meeting.

He had an outstanding intellect and was funny, kind, and original. He had enormous integrity and determination. Many, besides his family, will miss Mike for his very human qualities. He was always supportive, and intensely interested in the progress of younger colleagues. Although he could always see what was important and what was not, the verdict was communicated to others with unfailing courtesy. A natural countryman, Mike had a passion for fishing and gardening, and tragically his last illness cut short the rural retirement for which he had long yearned. In the adversity of his final illness, his fierce courage shone through; he died peacefully on 18 February 2003 at home in Dorset where he had been nursed devotedly by his much loved wife Anthea.

Peter Mills

Series Editor, Education in Heart

Roger Hall Editor, Heart 